\title{
Association between obesity and infarct size: insight into the obesity paradox.
}

\author{
Beatriz Cepeda-Valery, MD \\ Einstein Medical Center, Philadelphia, PA \\ Leandro Slipczuk, MD \\ Einstein Medical Center, Philadelphia, PA \\ Vincent M. Figueredo, M.D. \\ Thomas Jefferson University \\ Gregg S. Pressman \\ Einstein Medical Center

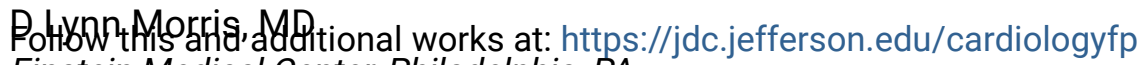 \\ Finstein Medical Center, Philadelphia, PA \\ Part of the Cardiology Commons

\section{Let us know how access to this document benefits you}

\section{Recommended Citation}

Cepeda-Valery, MD, Beatriz; Slipczuk, MD, Leandro; Figueredo, M.D., Vincent M.; Pressman, Gregg S.; Morris, MD, D Lynn; Lavie, MD, Carl J; and Romero-Corral, MD, Abel, "Association between obesity and infarct size: insight into the obesity paradox." (2013). Division of Cardiology Faculty Papers. Paper 34.

https://jdc.jefferson.edu/cardiologyfp/34

This Article is brought to you for free and open access by the Jefferson Digital Commons. The Jefferson Digital Commons is a service of Thomas Jefferson University's Center for Teaching and Learning (CTL). The Commons is a showcase for Jefferson books and journals, peer-reviewed scholarly publications, unique historical collections from the University archives, and teaching tools. The Jefferson Digital Commons allows researchers and interested readers anywhere in the world to learn about and keep up to date with Jefferson scholarship. This article has been accepted for inclusion in Division of Cardiology Faculty Papers by an authorized administrator of the Jefferson Digital Commons. For more information, please contact: JeffersonDigitalCommons@jefferson.edu. 


\section{Authors}

Beatriz Cepeda-Valery, MD; Leandro Slipczuk, MD; Vincent M. Figueredo, M.D.; Gregg S. Pressman; D Lynn Morris, MD; Carl J Lavie, MD; and Abel Romero-Corral, MD 


\section{As submitted to:}

\section{International Journal of Cardiology}

And later published as:

\section{Association Between Obesity and Infarct Size: Insight into the Obesity}

\section{Paradox}

\section{Volume 167, Issue 2, pages: 604-6, July 31, 2013}

\section{DOI: 10.1016/j.ijcard.2012.09.230}

Beatriz Cepeda-Valery ${ }^{1}$, Leandro Slipczuk ${ }^{2}$, Vincent M. Figueredo ${ }^{1}$, Gregg S Pressman ${ }^{1}$, D. Lynn Morris ${ }^{1}$, Carl J. Lavie ${ }^{3}$, Abel Romero-Corral ${ }^{1}$.

1. Einstein Institute for Heart and Vascular Health. Einstein Medical Center, Philadelphia, PA. This author takes responsibility for all aspects of the reliability and freedom from bias of the data presented and their discussed interpretation. 2.Department of Internal Medicine, Einstein Medical Center, Philadelphia, PA. Einstein Medical Center, Philadelphia, PA. This author takes responsibility for all aspects of the reliability and freedom from bias of the data presented and their discussed interpretation. 3.Department of Cardiovascular Diseases John Ochsner Heart \& Vascular Institute, New Orleans, LA and Department of Preventive Medicine, Pennington Biomedical Research Center, Louisiana State University Systems, Baton Rouge, LA. This author takes responsibility for all aspects of the reliability and freedom from bias of the data presented 
and their discussed interpretation.

\section{Correspondence to:}

Abel Romero-Corral, MD, MSc

Levy Building, Room 3232

Einstein Institute for Heart and Vascular Health.

Einstein Medical Center, 5501 Old York Rd, Philadelphia PA, 19141

Phone: (215) 4568991

Word count: 1,971 words excluding abstract, tables, figures and references

Key words: Obesity paradox, myocardial infarction, troponin, coronary heart disease, NSTEMI, STEMI. 


\section{Abbreviations:}

$\mathrm{BMI}=$ body mass index

$\mathrm{CHD}=$ Coronary heart disease

$\mathrm{CPK}=$ Creatinine phosphokinase

$\mathrm{CV}=$ Cardiovascular

$\mathrm{EAT}=$ Epicardial adipose tissue

$\mathrm{MI}=$ myocardial infarction

NSTEMI = Non-ST elevation myocardial infarction

PAT $=$ Pericardial adipose tissue

STEMI = ST elevation myocardial infarction

$\mathrm{WC}=$ Waist circumference 


\section{Abstract:}

Background: In patients with coronary heart disease, being overweight or obese is associated with better outcomes, a phenomenon known as the 'obesity paradox'. Despite the high prevalence of obesity in the United Sates, its effects on infarct size are largely unexplored.

Methods: Prospective cross-sectional study of 102 consecutive patients admitted with acute myocardial infarction (MI). Standardized forms were used to collect data on body mass index (BMI), waist circumference (WC), cardiovascular risk factors, and medications. Peak troponin I and creatinine phosphokinase (CPK) were used to estimate infarct size. Epicardial and pericardial fat were measured by echocardiography. We used univariate and multivariate analyses to assess whether obesity was associated with infarct size. Correlations between BMI, WC and cardiac fat with cardiac biomarkers were also performed.

Results: Mean age was $62 \pm 12$ years, and 55\% were men. Obesity was diagnosed in $69 \%$. On multivariate analysis, obesity was associated with greater infarct size in non-ST elevation MI $(\mathrm{p}=0.02)$. A positive correlation was observed between BMI and peak troponin I (rho=0.24, $\mathrm{p}=0.03$ ), and both, $\mathrm{BMI}$ and $\mathrm{WC}$ had a positive correlations with CPK levels (rho $=0.28, \&$ rho $=0.28$, both $\mathrm{p}=0.02$ ). However, in ST elevation MI, obesity was associated with smaller infarct size $(\mathrm{p}=0.05)$. Epicardial fat + pericardial fat had a negative correlation with peak CPK levels ( $\mathrm{rho}=-0.36, \mathrm{p}=0.05$ ).

Conclusions: We observed an opposite association between obesity and infarct size depending on the type of MI. These results were unexpected and may provide insight into the pathophysiology of the obesity paradox. (Word count: 244) 


\section{Introduction:}

Obesity has become the epidemic of our time. Studies using body fat to diagnose obesity estimate that 1 of every 2 people are obese $[1,2]$. Obesity contributes to the development of several cardiovascular $(\mathrm{CV})$ risk factors, including hypertension, diabetes, metabolic syndrome, dyslipidemia, and obstructive sleep apnea, and may be an independent risk factor for coronary heart disease (CHD) [3]. However, large epidemiologic studies have shown that, compared to normal weight people, overweight and obese subjects with $\mathrm{CV}$ diseases, including CHD and following an acute myocardial infarction (MI), have better outcomes [4], a phenomenon known as the "obesity paradox" [4-8].

It is well accepted that cardiac biomarkers reflect myocardial damage. Of the several cardiac biomarkers, troponin I best reflects infarct size [9, 10], showing an excellent correlation with infarct size, as measured by cardiac magnetic resonance $(\mathrm{r}=0.84)$, and has independent prognostic value [9-11].

Despite obesity being prevalent in patients with MI, its effects on infarct size are largely unexplored. The aim of this study was to examine associations between obesity and cardiac fat with infarct size estimated by peak troponin I and creatinine phosphokinase (CPK) levels. 


\section{Methods:}

\section{Study design and subject selection}

A prospective cross-sectional study of 102 consecutive patients aged 30 to 89 years who were admitted to the coronary care unit from March 2010 to March 2011 with the diagnosis of MI was performed. We excluded patients with recent cocaine use, severe congestive heart failure (ejection fraction <20\%), on hemodialysis, or with severe psychiatric conditions (unable to sign consent). Informed consent was obtained from each patient and the study protocol conforms to the ethical guidelines of the 1975 Declaration of Helsinki as reflected in a priori approval by the Einstein Healthcare Network Institutional Review Board. The authors of this manuscript have certified that they comply with the Principles of Ethical Publishing in the International Journal of Cardiology [12].

\section{Anthropometric measurements and obesity definition}

Standardized forms were used to collect data on anthropometric variables. Body weight was measured with an electronic load cell scale to the nearest $0.01 \mathrm{~kg}$. Height was measured to the nearest $0.1 \mathrm{~cm}$ using a fixed stadiometer. Waist circumference (WC) was determined using a measuring tape positioned at the high point of the iliac crest at the end expiration with the tape snug but not compressing the skin. Body mass index (BMI) was calculated as weight $(\mathrm{kg})$ divided by height $\left(\mathrm{m}^{2}\right)$. Obesity was defined according to American Heart Association as a BMI $\geq 30 \mathrm{~kg} / \mathrm{m}^{2}$ and $/$ or $\mathrm{WC} \geq 88 \mathrm{~cm}$ in women and $\geq 102$ $\mathrm{cm}$ in men [3]. 


\section{Abstraction of clinical data}

Standardized forms and medical records were used to obtain demographics and to determine the presence/absence of $\mathrm{CV}$ risk factors. Hypertension, diabetes, dyslipidemia, history of CHD and congestive heart failure were documented if self-reported by the patient or previously recorded on medical records, or if the patients were on medical therapy for those conditions. We further collected data on family history of premature CHD disease, smoking (current/former) and time of onset of chest pain. Screening for sleep apnea was performed by using the modified Berlin questionnaire [13]. Acute MI, non-ST elevation MI (NSTEMI), and ST elevation MI (STEMI) were defined according to American Heart Association and American College of Cardiology recommendations [14].

Laboratory data collected included complete blood count, fasting basic metabolic profile, fasting lipid profile and cardiac biomarkers (troponin I and CPK). We recorded peak troponin I and CPK levels as surrogates of infarct size as previously described [9-11]. At the time of admission, medications were recorded, including the use of antihypertensives, diuretics, nitrates, antiarrhythmics, diabetes medications, statins or any other lipid lowering therapy, antiplatelet and anticoagulation therapy.

\section{Echocardiographic and angiographic data}

Transthoracic Doppler echocardiography was performed and reported according to the American Society of Echocardiography guidelines [15]. Cardiac fat, including epicardial adipose tissue (EAT), pericardial adipose tissue (PAT) and EAT plus PAT (EAT+PAT) 
were measured by transthoracic echocardiography by a single operator (ARC) averaging 3 consecutive beats at end-systole in the parasternal long axis view [16].

Intraobserver variability was performed by re-measuring 10 randomly selected patients one month later $(\mathrm{r}=0.97, \mathrm{p}<0.0001)$. All measurements were performed blinded to clinical data of the patients. Angiographic data, including number of diseased vessels, as well as culprit vessel, were obtained from cardiac catheterization reports.

\section{Statistical analyses}

Data are reported as mean $\pm \mathrm{SD}$ for continuous variables, and number and $(\%)$ for categorical variables. This study was designed to detect a difference of $4 \mathrm{ng} / \mathrm{mL}$ in peak troponin I between obese and non-obese subjects with $80 \%$ power and a two-tail $\alpha=0.05$. To assess baseline differences by type of MI and obesity status we used Students t-test for continuous variables and $\mathrm{Chi}^{2}$ or Fishers exact test for categorical variables. We tested for normal distribution across the recorded variables, and we used the logarithm of peak troponin I and creatinine phosphokinase (CPK) due to the skewness of these continuous variables. Non-parametric correlations (Spearman) were performed to establish the association between BMI, WC, and cardiac fat with cardiac biomarkers. Due to significant difference in the peak troponin and CPK levels between NSTEMI and STEMI, analyses were reported separately. Two-tail p-values $<0.05$ were considered significant in advance. We performed univariate analyses to identify predictors of infarct size estimated by peak troponin I and CPK levels (p-value for inclusion <0.10). Multivariate analyses were performed to identify independent predictors of infarct size after adjustment for age, sex, race, traditional cardiovascular risk factors, obstructive 
sleep apnea, ejection fraction, three vessel disease, and time of onset of chest pain (pvalue $\leq 0.05$ ). Analyses were performed using JMP version 10.0 (SAS Institute, Cary, $\mathrm{NC})$. 


\section{Results:}

We enrolled 102 subjects (Table 1) of whom 73 (71.5\%) had NSTEMI. Mean age of the sample was $61 \pm 12$ years, and $56(55 \%)$ were men. Sixty-one percent were African American, 21\% Caucasian, 12\% Hispanic, and 6\% of other race. Obesity was present in 69\%. Comparing STEMI with NSTEMI (Table 1), those with STEMI were younger ( $58 \pm 12$ vs. $63 \pm 12$ years, $\mathrm{p}=0.05)$, had a lower prevalence of previously diagnosed CHD (14 vs. $45 \%, \mathrm{p}=0.002$ ), congestive heart failure ( 0 vs. $13 \%, \mathrm{p}=0.04$ ), and more PAT (8 83.1 vs. $6.6 \pm 2.8 \mathrm{~mm}, \mathrm{p}=0.05)$.

\section{Association between obesity and infarct size in NSTEMI patients}

Baseline characteristics, as well as CV risk factors and cardiac biomarkers between obese and non-obese subjects with NSTEMI are shown in Table 2A. Compared to non-obese subjects, those with obesity were more likely to be women (70 vs. $42 \%, \mathrm{p}=0.02)$ and diabetic (57 vs. $22 \%, \mathrm{p}=0.004$ ), had a high probability of having obstructive sleep apnea (68 vs. $13 \%, \mathrm{p}<0.0001)$, and had higher peak troponin I $(23.6 \pm 31$ vs. $17.8 \pm 37 \mathrm{ng} / \mathrm{mL}$, $\mathrm{p}=0.04)$ and CPK levels (590 \pm 549 vs. $334 \pm 274 \mathrm{U} / \mathrm{L}, \mathrm{p}=0.05)$-Figure 1A.

Significant univariate predictors for infarct size estimated by peak troponin I were hypertension $(\mathrm{p}=0.01)$, obesity $(\mathrm{p}=0.03)$ and possibly race $(\mathrm{p}=0.09)$, all of which were associated with higher troponin I. On multivariate analysis, obesity $(\mathrm{p}=0.02)$ remained a significant predictor of higher peak troponin I. Hypertension $(\mathrm{p}=0.01)$ and obesity $(\mathrm{p}=0.04)$ were significantly associated with higher peak CPK levels (Table 3A). On 
multivariate analysis both obesity $(\mathrm{p}=0.02)$ and hypertension $(\mathrm{p}=0.02)$ remained significant predictors for higher peak CPK (table 4A).

Correlations between BMI, WC, and cardiac fat with cardiac biomarkers are shown in Table 5A. BMI had a significant positive correlations with peak troponin I (rho=0.24, $\mathrm{p}=0.03$ ) and $\mathrm{CPK}(\mathrm{rho}=0.28, \mathrm{p}=0.02)$, while $\mathrm{WC}$ had a significant positive correlation with peak CPK (rho=0.24, $\mathrm{p}=0.05)$.

\section{Association between obesity and infarct size in STEMI patients}

Baseline characteristics, as well as $\mathrm{CV}$ risk factors and cardiac biomarkers between obese and non-obese subjects with STEMI are shown in Table 2B. Compared to non-obese subjects, those with obesity had more EAT $(7.1 \pm 2.2$ vs. $4.9 \pm 1.9 \mathrm{~mm}, \mathrm{p}=0.01)$, and EAT+PAT $(15.8 \pm 3.8$ vs. $11.5 \pm 4.7 \mathrm{~mm}, \mathrm{p}=0.03)$, and had lower peak troponin I $(104 \pm 141$ vs. $182 \pm 114 \mathrm{ng} / \mathrm{mL}, \mathrm{p}=0.02)$-Figure $1 B$.

Significant univariate predictors for infarct size estimated by peak troponin I were age $(\mathrm{p}=0.05)$ which was associated with higher peak troponin $\mathrm{I}$, while obesity $(\mathrm{p}=0.06)$, EAT $(\mathrm{p}=0.05)$, and EAT+PAT $(\mathrm{p}=0.07)$ were associated with lower peak troponin I. On multivariate analysis, only obesity $(\mathrm{p}=0.02)$ remained as a significant predictor for lower peak troponin I. For peak CPK levels, age $(\mathrm{p}=0.06)$, history of CHD $(\mathrm{p}=0.04)$ and diabetes $(\mathrm{p}=0.06)$, were significant predictors of higher peak CPK (Table 3B), while EAT+PAT $(\mathrm{p}=0.05)$ was associated with lower peak CPK. On multivariate analysis none 
of those remained significant, though there was a trend for diabetics $(p=0.08)$ to have higher peak CPK (Table 4B).

Correlations between BMI, WC, and cardiac fat with cardiac biomarkers are shown in table 5B. A trend towards a negative correlation was observed between EAT and EAT+PAT with peak troponin I $(\mathrm{rho}=-0.33, \mathrm{p}=0.08$, and rho=-0.34, $\mathrm{p}=0.07$, respectively), while a significant negative correlation was observed between EAT+PAT with peak $\mathrm{CPK}$ (rho=-0.36, $\mathrm{p}=0.05$ ). A trend towards a negative correlation was also observed between EAT and PAT with peak CPK levels (rho=-0.31, p=0.10, and rho=$0.34, \mathrm{p}=0.06$, respectively). 


\section{Discussion:}

The main finding of our study is that obesity has a significant and independent association with infarct size at the time of acute MI. Interestingly, obesity was associated with greater infarct size in patients with NSTEMI, while in patients with STEMI it was associated with smaller infarct size. To our knowledge, this is the first study to report an association between cardiac fat and infarct size. We also observed that EAT+PAT is associated with smaller infarct size among STEMI patients.

There are only a few small studies that have examined the association of obesity on infarct size. Pingitore, et al, performed cardiac magnetic resonances in 89 patients after their first MI (at least 3 months old) to assess the extent of MI size. They observed a smaller infarct size in obese patients. In should be noted that $>80 \%$ of their population were STEMI, and these findings are similar to our STEMI group [17]. In another study, Iglesias Bolanos, et al, studied the association between total and central obesity on infarct size in 40 men at the time of MI. Both BMI $(r=0.43)$ and WC $(r=0.47)$ showed a significant positive correlation with CPK (measured as AUC) [18]. These correlations are similar to our group of NSTEMI patients. It is important to note that Igleasias Bolanos study did not distinguished between STEMI and NSTEMI that in our study was noted to be an effect-modifier, meaning that obesity had opposite associations with infarct size by type of MI, and in fact, the interaction between BMI (but not WC) with peak troponin I by type of MI was statistically significant $(\mathrm{p}=0.005)$. 
Furthermore, we believe this is the first study looking at the association of cardiac fat measured by echocardiography with infarct size. We observed that EAT+PAT was associated with smaller infarct size in STEMI patients. Much recent work has focused on the pathophysiology of cardiac fat in cardiovascular disease, and our findings though interesting, need to be replicated in larger studies.

\section{Strengths and limitations}

Strengths of our study include the careful adjustment for potential confounders, including obstructive sleep apnea, which is rarely accounted for in obesity studies. In addition, we excluded other potential confounders, including patients on hemodialysis and severe congestive heart failure. Limitations of our study include a relatively small sample size, especially in the STEMI group ( $28.5 \%$ of MI), which could have limited our power to detect other possible associations with infarct size. Another potential limitation is the use cardiac biomarkers to estimate infarct size, instead of actually measuring infarct size by cardiac magnetic resonance or other novel technologies. However, recent work has shown that a single measurement of peak troponin I has an excellent correlation with infarct size [9-11].

\section{Conclusions}

We observed significant associations between obesity and infarct size. Interestingly, the direction of these associations varied by type of MI. While obesity was associated with greater infarct size in NSTEMI patients, obesity was associated with smaller infarct size 
in STEMI. These results were unexpected and may provide insight into the pathophysiology of the obesity paradox. 


\section{References:}

[1] Shah NR, Braverman ER. Measuring Adiposity in Patients: The Utility of Body Mass Index (BMI), Percent Body Fat, and Leptin. PLoS One. 2012;7:e33308.

[2] Romero-Corral A, Somers VK, Sierra-Johnson J, Thomas RJ, Collazo-Clavell ML, Korinek J, et al. Accuracy of body mass index in diagnosing obesity in the adult general population. Int J Obes (Lond). 2008;32:959-66.

[3] Cornier MA, Despres JP, Davis N, Grossniklaus DA, Klein S, Lamarche B, et al. Assessing adiposity: a scientific statement from the american heart association. Circulation. 2011;124:1996-2019.

[4] Romero-Corral A, Montori VM, Somers VK, Korinek J, Thomas RJ, Allison TG, et al. Association of bodyweight with total mortality and with cardiovascular events in coronary artery disease: a systematic review of cohort studies. Lancet. 2006;368:666-78. [5] Cepeda-Valery B, Pressman GS, Figueredo VM, Romero-Corral A. Impact of obesity on total and cardiovascular mortality--fat or fiction? Nat Rev Cardiol. 2011;8:233-7. [6] Lavie CJ, Milani RV, Ventura HO, Romero-Corral A. Body composition and heart failure prevalence and prognosis: getting to the fat of the matter in the "obesity paradox". Mayo Clin Proc. 2010;85:605-8.

[7] Lavie CJ, Milani RV, Ventura HO. Obesity and the "obesity paradox" in cardiovascular diseases. Clin Pharmacol Ther. 2011;90:23-5.

[8] Lavie CJ, Milani RV, Ventura HO. Impact of obesity on outcomes in myocardial infarction combating the "obesity paradox". J Am Coll Cardiol. 2011;58:2651-3.

[9] Chia S, Senatore F, Raffel OC, Lee H, Wackers FJ, Jang IK. Utility of cardiac biomarkers in predicting infarct size, left ventricular function, and clinical outcome after 
primary percutaneous coronary intervention for ST-segment elevation myocardial infarction. JACC Cardiovasc Interv. 2008;1:415-23.

[10] Di Chiara A, Dall'Armellina E, Badano LP, Meduri S, Pezzutto N, Fioretti PM. Predictive value of cardiac troponin-I compared to creatine kinase-myocardial band for the assessment of infarct size as measured by cardiac magnetic resonance. J Cardiovasc Med (Hagerstown). 2010;11:587-92.

[11] Hallen J, Buser P, Schwitter J, Petzelbauer P, Geudelin B, Fagerland MW, et al. Relation of cardiac troponin I measurements at 24 and 48 hours to magnetic resonancedetermined infarct size in patients with ST-elevation myocardial infarction. Am J Cardiol. 2009;104:1472-7.

[12] Coats AJ, Shewan LG. Statement on authorship and publishing ethics in the international journal of cardiology. Int J Cardiol. 2011;153:239-40.

[13] Netzer NC, Stoohs RA, Netzer CM, Clark K, Strohl KP. Using the Berlin Questionnaire to identify patients at risk for the sleep apnea syndrome. Ann Intern Med. 1999;131:485-91.

[14] Thygesen K, Alpert JS, White HD, Jaffe AS, Apple FS, Galvani M, et al. Universal definition of myocardial infarction. Circulation. 2007;116:2634-53.

[15] Lang RM, Bierig M, Devereux RB, Flachskampf FA, Foster E, Pellikka PA, et al. Recommendations for chamber quantification. Eur J Echocardiogr. 2006;7:79-108.

[16] Iacobellis G, Willens HJ. Echocardiographic epicardial fat: a review of research and clinical applications. J Am Soc Echocardiogr. 2009;22:1311-9; quiz 417-8. 
[17] Pingitore A, Di Bella G, Lombardi M, Iervasi G, Strata E, Aquaro GD, et al. The obesity paradox and myocardial infarct size. J Cardiovasc Med (Hagerstown). 2007;8:713-7.

[18] Iglesias Bolanos P, Olivar Roldan J, Penalver Talavera D, Diaz Guardiola P, Vega

Pinero B, Monereo Megias S. [Effect of abdominal obesity on size of myocardial infarction]. Endocrinol Nutr. 2009;56:4-8. 


\section{Figure legends}

Figure 1A. Cardiac biomarkers by obese status in NSTEMI patients.

Figure shows in the Y axis (log) peak troponin I and (log) peak CPK and in the $\mathrm{X}$ axis obese vs. non-obese patients with NSTEMI. There is a significant difference in cardiac biomarkers with higher levels in the obese group.

Figure 1B. Cardiac biomarkers by obese status in STEMI patients.

Figure shows in the $\mathrm{Y}$ axis $(\log )$ peak troponin I and $(\log )$ peak CPK and in the $\mathrm{X}$ axis obese vs. non-obese patients with STEMI. There is a significant difference in cardiac biomarkers with lower levels in the obese group.
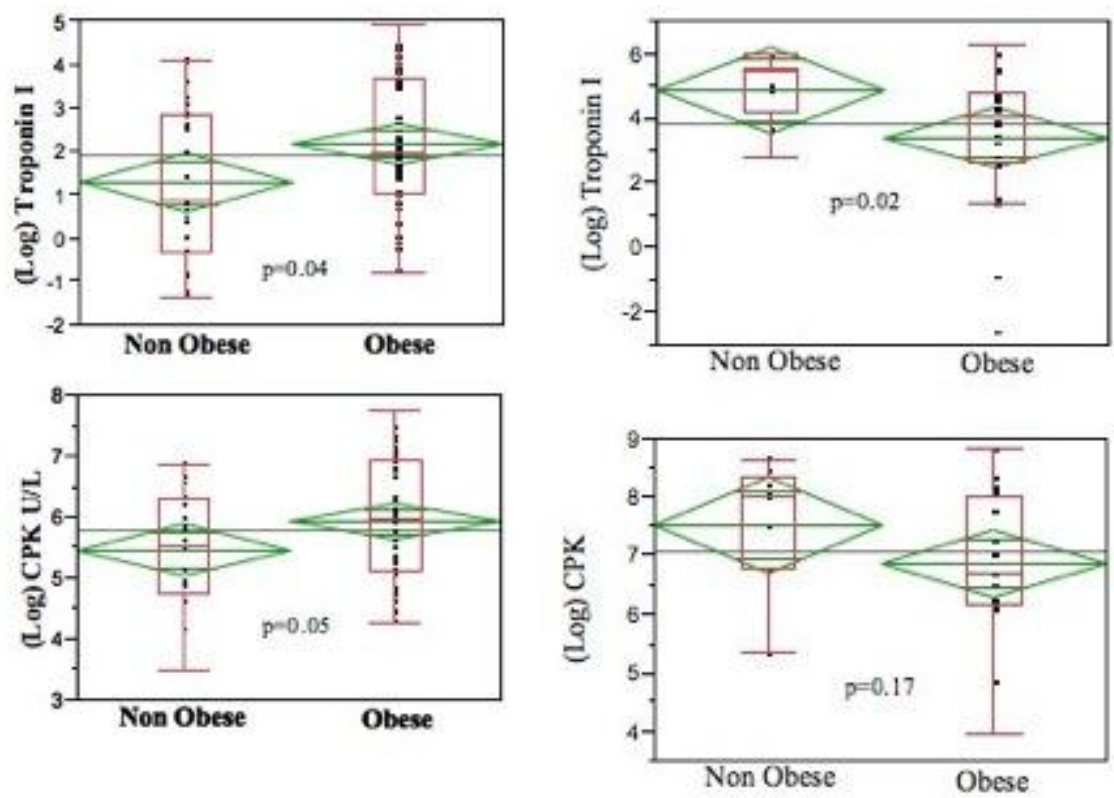


\section{Table 1 Baseline characteristics for all patients, and by type of AMI}

\begin{tabular}{|c|c|c|c|c|}
\hline Variable & $\begin{array}{c}\text { All } \\
\mathrm{n}=102\end{array}$ & $\begin{array}{c}\text { STEMI } \\
\mathbf{n}=29\end{array}$ & $\begin{array}{l}\text { NSTEMI } \\
\mathrm{n}=\mathbf{7 3}\end{array}$ & $+p$-value \\
\hline Age, years & $61.9 \pm 12$ & $58 \pm 12$ & $63 \pm 12$ & 0.05 \\
\hline Sex, men & $56(55)$ & $19(65)$ & $37(51)$ & 0.17 \\
\hline \multicolumn{5}{|l|}{ Race, $\%$} \\
\hline African-American & $62(61)$ & $18(62)$ & $44(60)$ & \\
\hline Caucasian & $22(21)$ & $7(24)$ & $15(21)$ & 0.79 \\
\hline Hispanic & $12(12)$ & $2(7)$ & $10(14)$ & \\
\hline Other & $6(6)$ & $2(7)$ & $4(5)$ & \\
\hline$*$ Obese, $\%$ & $70(69)$ & $20(69)$ & $50(68)$ & 0.96 \\
\hline BMI, $\mathrm{km} / \mathrm{m}^{2}$ & $30.1 \pm 6.7$ & $29.8 \pm 6$ & $30.3 \pm 7$ & 0.71 \\
\hline Waist circumference, $\mathrm{cm}$ & $102 \pm 17$ & $102 \pm 15$ & $102 \pm 18$ & 0.87 \\
\hline Epicardial Fat, $\mathrm{mm}$ & $6.2 \pm 2.2$ & $6.4 \pm 2.3$ & $6.1 \pm 2.2$ & 0.52 \\
\hline Pericardial Fat, mm & $7.0 \pm 2.9$ & $8.0 \pm 3.1$ & $6.6 \pm 2.8$ & 0.05 \\
\hline Epicardial + Pericardial Fat, $\mathrm{mm}$ & $13.2 \pm 4.6$ & $14.4 \pm 4.5$ & $12.7 \pm 4.5$ & 0.10 \\
\hline Hypertension, \% & $94(93)$ & $27(93)$ & $67(93)$ & 0.99 \\
\hline Diabetes, \% & $43(43)$ & $10(34)$ & $33(46)$ & 0.29 \\
\hline Dyslipidemia, \% & $81(80)$ & $20(69)$ & $72(85)$ & 0.07 \\
\hline Smoking, $\%$ & $47(47)$ & $12(41)$ & $35(48)$ & $\overline{0.50}$ \\
\hline Family history of coronary disease, $\%$ & $52(51)$ & $14(48)$ & $38(52)$ & 0.73 \\
\hline History of coronary artery disease, $\%$ & $37(36)$ & $4(14)$ & $33(45)$ & 0.002 \\
\hline Congestive heart failure, $\%$ & $9(9)$ & $0(0)$ & $9(13)$ & 0.04 \\
\hline Obstructive sleep apnea, \% & $55(54)$ & $18(62)$ & $37(51)$ & 0.29 \\
\hline Ejection fraction, $\%$ & $45 \pm 12$ & $44.6 \pm 12$ & $45.4 \pm 12$ & 0.78 \\
\hline $\begin{array}{l}\text { Onset of chest pain to peak enzyme, } \\
\text { hrs. }\end{array}$ & $16.7 \pm 16$ & $12 \pm 4.6$ & $18 \pm 19$ & 0.007 \\
\hline Triple vessel disease ${ }^{\wedge}, \%$ & $33(34)$ & $6(21)$ & $27(39)$ & 0.09 \\
\hline Creatinine, $\mathrm{mg} / \mathrm{dL}$ & $1.3 \pm 0.4$ & $1.39 \pm 0.4$ & $1.25 \pm 0.4$ & 0.18 \\
\hline+ Peak troponin I, ng/mL & $50.9 \pm 90$ & $128 \pm 136$ & $20 \pm 28$ & $<0.0001$ \\
\hline +Peak creatinine phosphokinase, U/L & $954 \pm 1263$ & $2017 \pm 181$ & $510 \pm 492$ & $<0.0001$ \\
\hline
\end{tabular}

$* \mathrm{BMI} \geq 30 \mathrm{~kg} / \mathrm{m}^{2}$ and $/$ or waist circumference $\geq 88 \mathrm{~cm}$ for women and $\geq 102 \mathrm{~cm}$ for men ** Comparison for STEMI vs. NSTEMI

$\wedge 98$ patients with angiographic results

+ Logarithm of peak troponin I and CPK was used to estimate p-values 
Table 2A: Characteristics in obese vs. non-obese subjects with NSTEMI

\begin{tabular}{lccc}
\hline Variable $\mathbf{n}=\mathbf{7 3}$ & $\begin{array}{c}* \text { Obese } \\
\mathbf{n = 5 0}\end{array}$ & $\begin{array}{c}\text { Non-Obese } \\
\mathbf{n = 2 3}\end{array}$ & p-value \\
\hline Age, years & $61.8 \pm 12.8$ & $67.1 \pm 12$ & 0.08 \\
\hline Sex, men & $21(42)$ & $16(70)$ & 0.02 \\
\hline Race, $\%$ & $32(64)$ & $12(52)$ & \\
African-American & $9(18)$ & $6(26)$ & 0.25 \\
Caucasian & $8(16)$ & $2(9)$ & \\
Hispanic & $1(2)$ & $3(13)$ & \\
Other & $33.1 \pm 6.4$ & $24.3 \pm 3.5$ & $<0.0001$ \\
\hline BMI, km/m ${ }^{2}$ & $110 \pm 15$ & $85 \pm 10$ & $<0.0001$ \\
\hline Waist circumference, cm & $6.1 \pm 2.2$ & $5.9 \pm 2.3$ & 0.76 \\
\hline Epicardial Fat, mm & $6.7 \pm 3.0$ & $6.3 \pm 2.4$ & 0.57 \\
\hline Pericardial Fat, mm & $12.9 \pm 4.7$ & $12.3 \pm 4.4$ & 0.62 \\
\hline Epicardial + Pericardial Fat, mm & $47(96)$ & $20(87)$ & 0.16 \\
\hline Hypertension, \% & $28(57)$ & $5(22)$ & 0.004 \\
\hline Diabetes, \% & $41(82)$ & $20(91)$ & 0.31 \\
\hline Dyslipidemia, \% & $23(47)$ & $12(52)$ & 0.67 \\
\hline Smoking, \% & $29(58)$ & $9(39)$ & 013 \\
\hline Family history of coronary disease, \% & $23(46)$ & $10(43)$ & 0.84 \\
\hline History of coronary artery disease, $\%$ & $4(8)$ & $5(23)$ & 0.08 \\
\hline Congestive heart failure, $\%$ & $34(68)$ & $3(13)$ & $<0.0001$ \\
\hline Obstructive sleep apnea, \% & $46.8 \pm 11$ & $42.1 \pm 14$ & 0.20 \\
\hline Ejection fraction, \% & $20.1 \pm 16$ & $15.3 \pm 23$ & 0.38 \\
\hline Onset of chest pain to peak enzyme, hrs. & $20(43)$ & $7(30)$ & 0.29 \\
\hline Triple vessel disease^, \% & $1.2 \pm 0.4$ & $1.2 \pm 0.4$ & 0.94 \\
\hline Creatinine, mg/dL & $23.6 \pm 31$ & $17.8 \pm 37$ & 0.04 \\
\hline +Peak troponin I, ng/mL & $590 \pm 549$ & $334 \pm 274$ & 0.05 \\
\hline +Peak creatinine phosphokinase, U/L & & & \\
\hline
\end{tabular}

$* \mathrm{BMI} \geq 30 \mathrm{~kg} / \mathrm{m}^{2}$ and/or waist circumference $\geq 88 \mathrm{~cm}$ for women and $\geq 102 \mathrm{~cm}$ for men $\wedge 70$ patients with angiographic results + Logarithm of peak troponin I and CPK was used to estimate p-values 
Table 2B Characteristics in obese vs. non-obese subjects with STEMI

\begin{tabular}{lccc}
\hline Variable $\mathbf{n = 2 9}$ & $\begin{array}{c}* \text { Obese } \\
\mathbf{n = 2 0}\end{array}$ & $\begin{array}{c}\text { Non-Obese } \\
\mathbf{n = 9}\end{array}$ & p-value \\
\hline Age, years & $59.3 \pm 13$ & $55.6 \pm 9$ & 0.41 \\
\hline Sex, men & $12(60)$ & $7(78)$ & 0.35 \\
\hline Race, $\%$ & & & \\
African-American & $13(65)$ & $5(56)$ & \\
Caucasian & $5(25)$ & $2(22)$ & 0.14 \\
Hispanic & $2(10)$ & $0(0)$ & \\
Other & $0(0)$ & $2(22)$ & \\
\hline BMI, km/m ${ }^{2}$ & $32.6 \pm 4.9$ & $23.5 \pm 3.2$ & $<0.0001$ \\
\hline Waist circumference, cm & $109 \pm 12$ & $86 \pm 9.7$ & $<0.0001$ \\
\hline Epicardial Fat, mm & $7.1 \pm 2.2$ & $4.9 \pm 1.9$ & 0.01 \\
\hline Pericardial Fat, mm & $8.6 \pm 3$ & $6.6 \pm 3.1$ & 0.12 \\
\hline Epicardial + Pericardial Fat, mm & $15.8 \pm 3.8$ & $11.5 \pm 4.7$ & 0.03 \\
\hline Hypertension, \% & $19(95)$ & $8(89)$ & 0.54 \\
\hline Diabetes, \% & $7(35)$ & $3(33)$ & 0.93 \\
\hline Dyslipidemia, \% & $15(75)$ & $5(26)$ & 0.29 \\
\hline Smoking, $\%$ & $6(30)$ & $6(67)$ & 0.06 \\
\hline Family history of coronary disease, \% & $11(55)$ & $3(33)$ & 0.28 \\
\hline History of coronary artery disease, $\%$ & $2(10)$ & $2(22)$ & 0.37 \\
\hline Congestive heart failure, $\%$ & $0(0)$ & $0(0)$ & - \\
\hline Obstructive sleep apnea, $\%$ & $14(70)$ & $4(44)$ & 0.18 \\
\hline Ejection fraction, \% & $47 \pm 11$ & $39 \pm 12$ & 0.15 \\
\hline Onset of chest pain to peak enzyme, hrs. & $12.4 \pm 4.6$ & $11.2 \pm 4.8$ & 0.55 \\
\hline Triple vessel disease^, \% & $3(16)$ & $3(33)$ & 0.29 \\
\hline Creatinine, mg/dL & $1.3 \pm 0.3$ & $1.4 \pm 0.7$ & 0.62 \\
\hline+ +Peak troponin I, ng/mL & $104 \pm 141$ & $182 \pm 114$ & 0.02 \\
\hline +Peak creatinine phosphokinase, U/L & $1723 \pm 1776$ & $2636 \pm 1848$ & 0.17 \\
\hline & & &
\end{tabular}

$* \mathrm{BMI} \geq 30 \mathrm{~kg} / \mathrm{m}^{2}$ and/or waist circumference $\geq 88 \mathrm{~cm}$ for women and $\geq 102 \mathrm{~cm}$ for men $\wedge 28$ patients with angiographic results

+ Logarithm of peak troponin I and CPK was used to estimate p-values 
Table 3A Univariate predictors of peak troponin I and CPK levels in NSTEMI

Variable for peak troponin I

F-ratio

p-value

\begin{tabular}{|l|c|c|}
\hline Hypertension & 6.00 & 0.017 \\
\hline *Obesity & 4.59 & 0.035 \\
\hline Race & 2.91 & 0.092 \\
\hline
\end{tabular}

Variable for peak CPK

F-ratio

p-value

\begin{tabular}{|l|c|c|}
\hline Hypertension & 6.97 & 0.010 \\
\hline *Obesity & 4.13 & 0.046 \\
\hline
\end{tabular}

$* \mathrm{BMI} \geq 30 \mathrm{~kg} / \mathrm{m}^{2}$ and $/$ or waist circumference $\geq 88 \mathrm{~cm}$ for women and $\geq 102 \mathrm{~cm}$ for men

Table 3B Univariate predictors of peak troponin I and CPK levels in STEMI

Variable for peak troponin I

\begin{tabular}{|l|c|c|}
\hline Epicardial + Pericardial Fat & -4.02 & 0.055 \\
\hline Age & 3.92 & 0.057 \\
\hline *Obesity & -3.66 & 0.066 \\
\hline Epicardial fat & -3.43 & 0.075 \\
\hline
\end{tabular}

Variable for peak CPK

F-ratio p-value

\begin{tabular}{|l|c|c|}
\hline History of coronary artery disease & 4.36 & 0.047 \\
\hline Epicardial + Pericardial Fat & -3.94 & 0.058 \\
\hline Diabetes & 3.77 & 0.063 \\
\hline Age & 3.47 & 0.074 \\
\hline
\end{tabular}

$* \mathrm{BMI} \geq 30 \mathrm{~kg} / \mathrm{m}^{2}$ and $/$ or waist circumference $\geq 88 \mathrm{~cm}$ for women and $\geq 102 \mathrm{~cm}$ for men 


\section{Table 4A Multivariate predictors of peak troponin I and CPK levels in}

NSTEMI

\begin{tabular}{|l|c|c|} 
Variable for peak troponin I & F-ratio & p-value \\
\hline *Obesity & 5.43 & 0.023 \\
\hline Hypertension & 2.96 & 0.091 \\
\hline \multicolumn{3}{|l|}{} \\
Variable for peak CPK & F-ratio & p-value \\
\hline Hypertension & 5.42 & 0.024 \\
\hline *Obesity & 5.38 & 0.024 \\
\hline
\end{tabular}

$* \mathrm{BMI} \geq 30 \mathrm{~kg} / \mathrm{m}^{2}$ and/or waist circumference $\geq 88 \mathrm{~cm}$ for women and $\geq 102 \mathrm{~cm}$ for men

Table 4B Multivariate predictors of peak troponin I and CPK levels in STEMI

\begin{tabular}{|l|c|c|}
\hline Variable for peak troponin I & F-ratio & p-value \\
\hline *Obesity & -4.47 & 0.054 \\
\hline Variable for peak CPK & F-ratio & p-value \\
\hline Diabetes & 3.48 & 0.086 \\
\hline
\end{tabular}

$* \mathrm{BMI} \geq 30 \mathrm{~kg} / \mathrm{m}^{2}$ and $/$ or waist circumference $\geq 88 \mathrm{~cm}$ for women and $\geq 102 \mathrm{~cm}$ for men

Multivariate analyses adjusted for: Age, sex, race, hypertension, diabetes, dyslipidemia, smoking, history of coronary disease, congestive heart failure, obstructive sleep apnea, triple vessel disease and time of onset of chest pain. 
Table 5A Correlations between BMI, waist circumference, epicardial fat, pericardial fat and epicardial + pericardial fat with peak troponin I and CPK in patients with NSTEMI

\begin{tabular}{|lcc|}
\hline & Peak Troponin I & Peak CPK \\
\hline BMI & $0.24, \mathrm{p}=0.03$ & $0.28, \mathrm{p}=0.02$ \\
\hline Waist circumference & $0.12, \mathrm{p}=\mathrm{NS}$ & $0.24, \mathrm{p}=0.05$ \\
\hline Epicardial Fat & $0.08, \mathrm{p}=\mathrm{NS}$ & $0.04 . \mathrm{p}=\mathrm{NS}$ \\
\hline Pericardial Fat & $-0.06, \mathrm{p}=\mathrm{NS}$ & $-0.07, \mathrm{p}=\mathrm{NS}$ \\
\hline Epicardial and Pericardial Fat & $0.01, \mathrm{p}=\mathrm{NS}$ & $-0.03, \mathrm{p}=\mathrm{NS}$ \\
\hline
\end{tabular}

$\mathrm{NS}=\mathrm{p}$-value $>0.10$

Table 5B Correlations between BMI, waist circumference, epicardial fat, pericardial fat and epicardial + pericardial fat with peak troponin I and CPK in patients with STEMI

\begin{tabular}{|lcc|}
\hline & Peak Troponin I & Peak CPK \\
\hline BMI & $-0.25, \mathrm{p}=\mathrm{NS}$ & $-0.18, \mathrm{p}=\mathrm{NS}$ \\
\hline Waist circumference & $-0.05, \mathrm{p}=\mathrm{NS}$ & $-0.02, \mathrm{p}=\mathrm{NS}$ \\
\hline Epicardial Fat & $-0.33, \mathrm{p}=0.08$ & $-0.31, \mathrm{p}=0.10$ \\
\hline Pericardial Fat & $-0.29, \mathrm{p}=\mathrm{NS}$ & $-0.34, \mathrm{p}=0.06$ \\
\hline Epicardial and Pericardial Fat & $-0.34, \mathrm{p}=0.07$ & $-0.36, \mathrm{p}=0.05$ \\
\hline
\end{tabular}

$\mathrm{NS}=\mathrm{p}$-value $>0.10$ 